\title{
RADIOCARBON DATING OF SCROLLS AND LINEN FRAGMENTS FROM THE JUDEAN DESERT
}

\section{A. J. TIMOTHY JULL, ${ }^{1}$ DOUGLAS J. DONAHUE, ${ }^{1}$ MAGEN BROSHI ${ }^{2}$ and EMANUEL TOV ${ }^{3}$}

\begin{abstract}
We report on new ${ }^{14} \mathrm{C}$ measurements of samples of 18 texts (scrolls) and 2 linen fragments from Qumran Caves 1,2 , and 4 and from Na hal Hever, both in the Dead Sea region. The radiocarbon results are in good agreement with estimates of age based on paleography.
\end{abstract}

\section{INTRODUCTION}

Various parchment and papyrus manuscripts found in caves in the area of Qumran and at other sites in the Judean Desert are known generally as the Dead Sea Scrolls. The Qumran scrolls are generally considered to have been hidden by the Qumran Community, identified by most scholars as the Essenes. The documents are usually regarded to have been copied between the mid-third century BC and $\mathrm{AD}$ 68, when the Qumran settlement was destroyed by the Romans.

Bonani et al. $(1991,1992)$ dated 14 texts, 8 of which came from Qumran. We present here new radiocarbon dates of 18 texts, including 3 date-bearing texts ( 3 from Qumran Cave 1, 12 from Cave 4 , and 3 from other sites in the Judean Desert). We consider the importance of the ${ }^{14} \mathrm{C}$ dates in relation to other age estimates and we also report on ${ }^{14} \mathrm{C}$ examinations of linen fragments from the Judean Desert.

\section{METHODS}

All except three of the scroll samples were taken on 21 and 22 March 1994 by museum staff in the presence of the authors at either the Rockefeller or Israel Museums (see Table 1). Three additional samples (DSS-50, -52 and -53) were taken later at the Shrine of the Book and sent to Tucson for analysis. All samples were taken from ragged edges of top or bottom margins of the scrolls. No samples were taken that would have caused any significant damage to the scrolls themselves. The sizes of the samples are listed in Table 1. Most of the documents from the Judean Desert had been suggested to us by colleagues who had special interests in ${ }^{14} \mathrm{C}$ analysis of particular texts.

Some samples from date-bearing documents were added as control texts (DSS-25, -52 and -53 ), and the identity and ages of these materials were unknown to the Arizona AMS laboratory at the time of measurement. One control sample had been dated previously at ETH-Zürich in 1990-1991 (DSS50). The identity of this sample was also unknown to the Arizona laboratory at the time of measurement. Photographic records were made of the exact locations of the pieces subjected to examination. In some cases, scrolls suggested as important for dating had insufficient material available in the margins or the margins were too beautiful to be harmed. These samples were not taken and they account for the missing numbers in the lists (e.g., DSS-2).

\section{Sample Types and Treatment}

Small samples of 5-15 mg of material were removed. Samples were studied under a binocular microscope and were divided into three types:

\footnotetext{
${ }^{1}$ NSF Arizona Accelerator Mass Spectrometer Facility, The University of Arizona, Tucson, Arizona 85721 USA

${ }^{2}$ Shrine of the Book, Israel Museum, Jerusalem 91710 Israel

${ }^{3}$ Dead Sea Scrolls Publication Project, Department of the Bible, Hebrew University, Jerusalem, Israel
} 
TABLE 1. Description and Weights of Dead Sea Scroll Samples and Related Materials

\begin{tabular}{|c|c|c|c|c|}
\hline Sample & Q no. & Description & $\begin{array}{c}\text { Museum } \\
\text { no.* }\end{array}$ & $\begin{array}{c}\text { Weight } \\
\text { (mg) }\end{array}$ \\
\hline DSS-1 & $4 Q 266\left(D^{a}\right)$ & Damascus Document, a & 706 & 23.35 \\
\hline DSS-3 & 1QpHab & Commentary on Habakkuk & Shrine $\dagger$ & 31.00 \\
\hline DSS-4 & $1 \mathrm{QS}$ & Community Rule & Shrine & 14.20 \\
\hline DSS-5 & $4 Q 258$ & Community Rule, $d$ & 140 & 14.90 \\
\hline DSS-7 & 4Q171 $\left(\mathrm{pPs}^{\mathrm{a}}\right)$ & Commentary on Psalms, a & 600 & 11.70 \\
\hline DSS-8 & $4 Q 521$ & Messianic Apocalypse & 330 & 4.90 \\
\hline DSS-9 & $4 Q 267\left(D^{b}\right)$ & Damascus Document, b & 107 & 7.80 \\
\hline DSS-10 & $4 Q 249$ & Midrash Sepher Moshe & 590 & 6.20 \\
\hline DSS-11 & 4Q317 & Phases of the Moon & 899 & 19.30 \\
\hline DSS-13 & $4 Q 208$ & Astronomical Enocha & 823 & 19.20 \\
\hline DSS-19 & $4 \mathrm{Q} 22$ & PaleoExodus $^{\mathrm{m}}$ & 661 & 6.75 \\
\hline DSS-19P & 4Q22 patch & Patch on $4 \mathrm{Q} 22$ & 661-P & 10.70 \\
\hline DSS-22 & $4 \mathrm{Q} 342$ & Letter & 602 & 23.70 \\
\hline DSS-23 & 4Q344 & Debt acknowledgment & 602 & 9.56 \\
\hline DSS-24 & 4Q345 & Sale of land & 602 & 14.40 \\
\hline DSS-25 & Pap Yadin 21 & Papyrus, AD 130 & Shrine & 5.24 \\
\hline DSS-26 & Cave 4 & Linen & 1041 & 30.70 \\
\hline DSS-27 & Cave 2 & Linen & 749 & 21.70 \\
\hline DSS-50 & $1 Q I s a^{a}$ & Book of Isaiah ${ }^{a}$ & Shrine & 56.50 \\
\hline DSS-52 & Kefar Bebayou & Papyrus & Shrine & 20.20 \\
\hline DSS-53 & Pap Yadin 19 & Papyrus, AD 128 & Shrine & 18.20 \\
\hline
\end{tabular}

*All items derive from the Rockefeller Museum, Jerusalem, unless otherwise indicated. $\dagger$ Items from the Shrine of the Book, Israel Museum

\section{Type 1. Parchment samples that appeared to be relatively clean}

Pieces of $c a .2-10 \mathrm{mg}$ were pretreated using procedures based on those reported by Bonani $e$ al . $(1991,1992)$ with some modifications. Samples were washed in $1 \mathrm{~N} \mathrm{HCl}$ for $10 \mathrm{~min}$, rinsed in distilled water, washed in $0.1 \% \mathrm{NaOH}$ for up to $10 \mathrm{~min}$, rinsed again in distilled water, and finally reacidified with $\mathrm{HCl}$, and cleaned with distilled water. Samples were dried in a vacuum oven and were removed as soon as they were dry. We found that some partially gelatinized samples were very easily dissolved by $\mathrm{NaOH}$ solutions (as previously reported by Bonani et al. 1991 and 1992), and all samples were monitored during this process. Samples that started to dissolve in $\mathrm{NaOH}$ were removed from the solution as quickly as possible.

\section{Type 2. Parchment samples with glue contamination}

These samples were contaminated with perspex glue, as they had been stuck to rice paper as a backing material. They included DSS-1, $-5,-11,-22,-23$ and -24 . DSS-4 was difficult to clean, as it had been attached to a silk backing material and also appeared to be impregnated with a glue-like material. Pieces of $2-8 \mathrm{mg}$ with adhering glue were washed in acetone in an ultrasonic bath for $30 \mathrm{~min}$. This procedure worked well for most samples, but in the case of two sample pieces (DSS-23 and -24), this process had to be repeated for three hours. The samples were then subjected to the same pretreatment routine as the first batch.

\section{Type 3. Papyri}

Papyrus samples (DSS-10, $-25,-52,-53$ ) were generally very clean. Pretreatment was carried out easily using the standard methods of Type 1 , above. 
Dried samples were combusted with $\mathrm{CuO}$ to make $\mathrm{CO}_{2}$ using the standard techniques at Arizona (Donahue, Jull and Toolin 1990). For most samples, sufficient $\mathrm{CO}_{2}$ sample was available, and a split of up to $0.2 \mathrm{ml}$ was taken for stable-isotope analysis of the $\delta^{13} \mathrm{C}$ of the carbon. This parameter is important to make accurate corrections to the ${ }^{14} \mathrm{C}$ age, which are all quoted as normalized to $-25 \%$ (Stuiver and Polach 1977). The remaining $\mathrm{CO}_{2}$ was converted to graphite using standard procedures. The graphite powder so produced was pressed into an accelerator target holder, and the target was then analyzed by accelerator mass spectrometry (AMS). We loaded 24 sample targets with 8 standard targets (consisting of 4 standard graphites made from NIST HOxI and 4 of HOxII). In most cases, several separate preparations of samples were performed. A general description of the AMS measurements is given by Donahue, Jull and Toolin (1990). ${ }^{14} \mathrm{C}$ results were calculated using the procedures reported by Donahue, Linick and Jull (1990).

\section{RESULTS AND DISCUSSION}

\section{Written Texts}

Table 2 presents the results of the ${ }^{14} \mathrm{C}$ and $\delta^{13} \mathrm{C}$ measurements. The results are reported as conventional ${ }^{14} \mathrm{C}$ ages in years before present ( $\left.\mathrm{AD} 1950\right)$, with errors on one standard deviation (1 $\sigma$ ), and calibrated ages obtained using both $1-\sigma$ and $2-\sigma$ confidence intervals, using the calibration of Stuiver and Pearson (1986). For samples with insufficient material for both ${ }^{14} \mathrm{C}$ and $\delta^{13} \mathrm{C}$ measurements, an average value of $\delta^{13} \mathrm{C}$ was estimated from results of other scrolls, and this value is given in parentheses. Also included in Table 2 are ages determined by paleographic analysis. In Appendix 1 , we present further information about the sources of the paleographic age estimates.

The dates reported in Table 2 were obtained in most cases by multiple measurements of several subsamples. All ${ }^{14} \mathrm{C}$ ages were corrected to a $\delta^{13} \mathrm{C}$ value of $-25 \%$, from the values indicated (Donahue, Linick and Jull 1990). This small isotope correction is a standard convention of ${ }^{14} \mathrm{C}$ measurements (Stuiver and Polach 1977). The best precisions are ca. \pm 20 BP. For other samples where larger uncertainties are quoted, the precision was limited either by scatter in the individual measurements, or by the fact that only a few independent measurements were made, due to sample-size limitations. The calibration curve used to obtain the calendar age was the 20 -yr average of Stuiver and Pearson (1986), although in some cases we also refer to the 10-yr average curve of Stuiver and Becker (1986). Calculations of probability are quoted for 2- $\sigma$ ranges, where the calibration program (Stuiver and Reimer 1986) produces two ranges.

With one exception, the dates of the documents determined by the ${ }^{14} \mathrm{C}$ agree well with the dates previously suggested on the basis of paleographical analysis. These results are summarized in Figure 1, which shows the calibrated ${ }^{14} \mathrm{C}$ ages plotted against paleographic age estimates. The calibrated age ranges are derived by applying the ${ }^{14} \mathrm{C}$ age with uncertainties of $2 \sigma$ to the calibration curve of Stuiver and Pearson (1986). One exception was the first set of dates on 4Q258 (DSS-5), which was anomalously young and difficult to explain in terms of the expected age of the material. A second and cleaner sample of material was removed for dating. This second sample was subjected to an extensive acetone cleaning as described for Type 2 samples, as well as the acid-base-acid treatment, and gave ${ }^{14} \mathrm{C}$ age comparable to the paleographic age.

\section{Samples of Known Age}

Samples in Table 2 listed as DSS-25, -52 and -53 are all papyri of precisely known age, since they bear written dates. For the two papyri, DSS-25 (pap Yadin 21) and -53 (pap Yadin 19), our results agree within $1 \sigma$ with known values. For DSS-52, the 2- $\sigma$ range of our measurements fails by $10 \mathrm{yr}$ 
TABLE 2: Radiocarbon Dates on Dead Sea Scrolls and Related Materials Measured at The University of Arizona

\begin{tabular}{|c|c|c|c|c|c|c|}
\hline Sample no. & Sample & $\begin{array}{l}\text { No. of } \\
\text { runs* }\end{array}$ & $\begin{array}{l}\delta^{13} \mathrm{C} \\
(\% 0) \dagger\end{array}$ & $\begin{array}{l}{ }^{14} \mathrm{C} \text { age } \\
\text { (yr BP) }\end{array}$ & Calibrated age & $\begin{array}{l}\text { Paleographic } \\
\text { age }\end{array}$ \\
\hline AA-13415 & DSS-1 4Q266 & 5 & -22.1 & $1954 \pm 38$ & 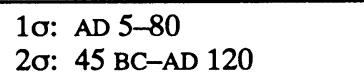 & $100-50$ вс \\
\hline AA-13417 & DSS-3 1QpHab & 8 & -20.8 & $2054 \pm 22$ & $\begin{array}{ll}1 \sigma: & 104-43 \mathrm{BC} \\
2 \sigma & 153-143 \mathrm{BC}(3 \%) \\
& 120-5 \mathrm{BC}(97 \%)\end{array}$ & $30-1 \mathrm{BC}$ \\
\hline AA-13418 & DSS-4 1QS & 3 & $(-21.2)$ & $2041 \pm 68$ & 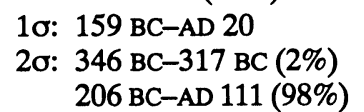 & $100-75$ BC \\
\hline $\begin{array}{l}\text { AA-13419 } \\
\text { (first sample) }\end{array}$ & DSS-5A 4Q258 & 5 & -22.6 & $1823 \pm 24$ & 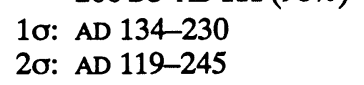 & $\sim 100 \mathrm{BC}$ \\
\hline $\begin{array}{l}\text { AA- } 16060 \\
\text { (second samp) }\end{array}$ & $\begin{array}{l}\text { DSS-5B 4Q258 } \\
\text { le) }\end{array}$ & 4 & -21.4 & $1964 \pm 45$ & $\begin{array}{l}\text { 1б: } 11 \text { BC-AD } 78 \\
2 \sigma: 95 \text { BC-AD } 122\end{array}$ & $\sim 100 \mathrm{BC}$ \\
\hline AA-13420 & DSS-7 4Q171 & 7 & $(-21.2)$ & $1944 \pm 23$ & $\begin{array}{l}1 \sigma: \text { AD } 22-78 \\
2 \sigma: \text { AD 5-111 }\end{array}$ & \\
\hline AA-13421 & DSS-8 4Q521 & 4 & $(-21.2)$ & $1984 \pm 33$ & $\begin{array}{l}1 \sigma: 35 \text { BC-AD } 59 \\
2 \sigma: 93 \text { BC-AD } 80\end{array}$ & $100-80 \mathrm{BC}$ \\
\hline AA-13422 & DSS-9 4Q267 & 5 & -21.6 & $2094 \pm 29$ & $\begin{array}{l}1 \sigma: 172-98 \mathrm{BC} \\
2 \sigma: 194-45 \mathrm{BC}\end{array}$ & $50-0 \mathrm{BC}$ \\
\hline AA-13423 & DSS-10 4Q249 & 6 & -10.8 & $2097 \pm 50$ & $\begin{aligned} \text { 1б: } & 191-90 \mathrm{BC} \\
2 \sigma: & 380-354 \mathrm{BC}(8 \%) \\
& 242 \mathrm{BC}-\mathrm{AD} 6(92 \%)\end{aligned}$ & \\
\hline AA-13244 & DSS-11 4Q317 & 4 & -20.9 & $2084 \pm 30$ & $\begin{array}{l}\text { 1б: } 164-93 \mathrm{BC} \\
2 \sigma: 191-36 \mathrm{BC}\end{array}$ & \\
\hline AA- 13245 & DSS-13 4Q208 & 9 & -21.0 & $2095 \pm 20$ & $\begin{array}{l}1 \sigma: 166-102 \mathrm{BC} \\
2 \sigma: 186-92 \mathrm{BC}\end{array}$ & $\sim 200 \mathrm{BC}$ \\
\hline AA-13246 & DSS-19 4Q22 & 2 & $(-21.2)$ & $2044 \pm 65$ & 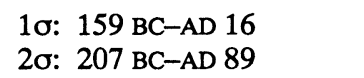 & $100-25$ вС \\
\hline AA-13426P & $\begin{array}{l}\text { DSS-19a 4Q22 } \\
\text { Patch }\end{array}$ & 4 & $(-21.2)$ & $2024 \pm 39$ & $\begin{array}{l}1 \sigma: 98 \mathrm{BC}-\mathrm{AD} 13 \\
2 \sigma: 120 \mathrm{BC}-\mathrm{AD} 63\end{array}$ & 50 BC-AD 50 \\
\hline AA-13430 & DSS-22 4Q342 & 4 & -20.8 & $1934 \pm 47$ & $\begin{array}{l}1 \sigma: \mathrm{AD} 14-115 \\
2 \sigma: 43 \mathrm{BC}-\mathrm{AD} 141\end{array}$ & \\
\hline AA-13431 & DSS-23 4Q344‡ & 3 & -20.4 & $1902 \pm 39$ & 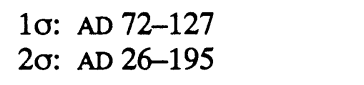 & \\
\hline AA-13432 & DSS-24 4Q345 & 5 & -19.7 & $2185 \pm 60$ & $\begin{array}{l}1 \sigma: \quad 373-171 \mathrm{BC} \\
2 \sigma: 390-100 \mathrm{BC}\end{array}$ & \\
\hline AA-13433 & $\begin{array}{l}\text { DSS- } 255 / 6 \mathrm{Hev} \\
21 \text { (pap Yadin } 21 \text { ) }\end{array}$ & 3 & -12.0 & $1799 \pm 57$ & $\begin{array}{l}\text { 1б: } \mathrm{AD} 130-321 \\
2 \sigma: \mathrm{AD} 80-380\end{array}$ & $\mathrm{AD} 130$ \\
\hline AA-14984 & DSS-50 1QIsa ${ }^{a}$ & 5 & -20.4 & $2141 \pm 32$ & 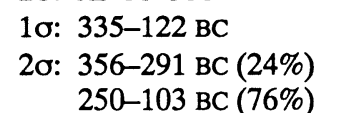 & $150-125 \mathrm{BC}$ \\
\hline AA-14986 & $\begin{array}{l}\text { DSS-52 Kefar } \\
\text { Bebayou }\end{array}$ & 4 & -10.0 & $1758 \pm 36$ & $\begin{array}{l}1 \sigma: \text { AD } 231-332 \\
2 \sigma: \text { AD } 144-370 \S\end{array}$ & $\mathrm{AD} 135$ \\
\hline AA-14987 & $\begin{array}{l}\text { DSS-53 5/6 } \\
\text { Hev } 21\end{array}$ & 4 & -10.8 & $1827 \pm 36$ & $\begin{array}{c}\text { 10: } \mathrm{AD} 126-234 \\
\mathrm{AD} 86-314\end{array}$ & AD 128 \\
\hline
\end{tabular}

*The number of independent determinations of ${ }^{14} \mathrm{C}$ age

†Values in parentheses are estimated based on the mean values for Dead Sea Scroll parchments.

$¥$ The documentary texts $4 \mathrm{Q} 342$ (letter in Judeo-Aramaic) and $4 \mathrm{Q} 344$ (debt acknowledgment) can be dated as late as the Bar-Kokhba period, and such a late date confirms doubts regarding the Qumranic origin of these texts. These fragments, bought from a Bedouin, were probably mixed up with the Qumran fragments by antiquity dealers (M. Broshi).

$\S$ The 10-yr average calibration curve of Stuiver and Becker (1986) gave AD 133-386 (2б) for this sample. 


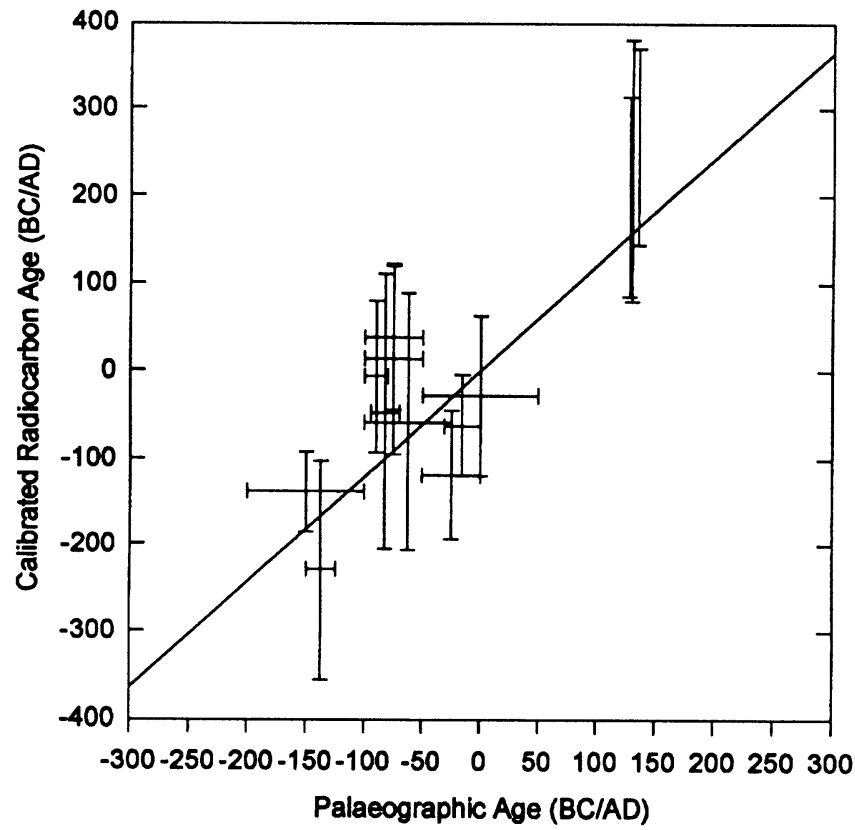

Fig. 1. Calibrated ${ }^{14} \mathrm{C}$ age ranges vs. estimated paleographic ages of scroll samples. The calibrated ranges were deduced from measured conventional ${ }^{14} \mathrm{C}$ ages, including $2 \sigma$, using the tree-ring calibration curve of Stuiver and Pearson (1986). The ranges of paleographic estimates were chosen to include the range of the estimates reported in Appendix 1.

to include the known age. Interestingly, if the decadal tree-ring calibration curve of Stuiver and Becker (1986) is used, the 2- $\sigma$ range of our measurement would be AD 133-386, and would include the known age. For a range produced by using the measured ${ }^{14} \mathrm{C}$ age and $1 \sigma$, the expectation is that there is a $68 \%$ probability that the range encompasses the correct age of the document. If $2 \sigma$ are used, the probability is $95 \%$. It is also true that, in comparing known ages with a possible range of ages obtained from ${ }^{14} \mathrm{C}$ measurements, the procedures for producing the calibrated age are such that the actual age can fall anywhere within the calculated limits.

\section{Comparison to Zürich ${ }^{14} \mathrm{C}$ Measurements}

Sample DSS-50, which had been tested previously at the ETH Zürich Laboratory, was also measured in our study. This sample was taken from the same area of the scroll as the Zürich sample, from column XXXIX of the large Isaiah scroll from Cave 1 . The ${ }^{14} \mathrm{C}$ results of Bonani et al. (1991, 1992) yielded the result of $2128 \pm 38$ BP (ETH-6651), which is in excellent agreement with our value, $2141 \pm 32 \mathrm{BP}$ (AA-14984). We report the calibrated age range in Table 2 . The weighted mean of the two measurements is $2136 \pm 24 \mathrm{BP}$.

\section{Comparison of Results to the Calibration Curve}

All of the results discussed are presented graphically in Figure 2 . The individual points are obtained by plotting the measured conventional ${ }^{14} \mathrm{C}$ ages of the samples on the ordinate $v s$. the estimated paleographic ages of the samples on the abscissa. The fact that the individual points plot within $2 \sigma$ of the calibration curve indicates that the ${ }^{14} \mathrm{C}$ and paleographic ages are in reasonable agreement. It 


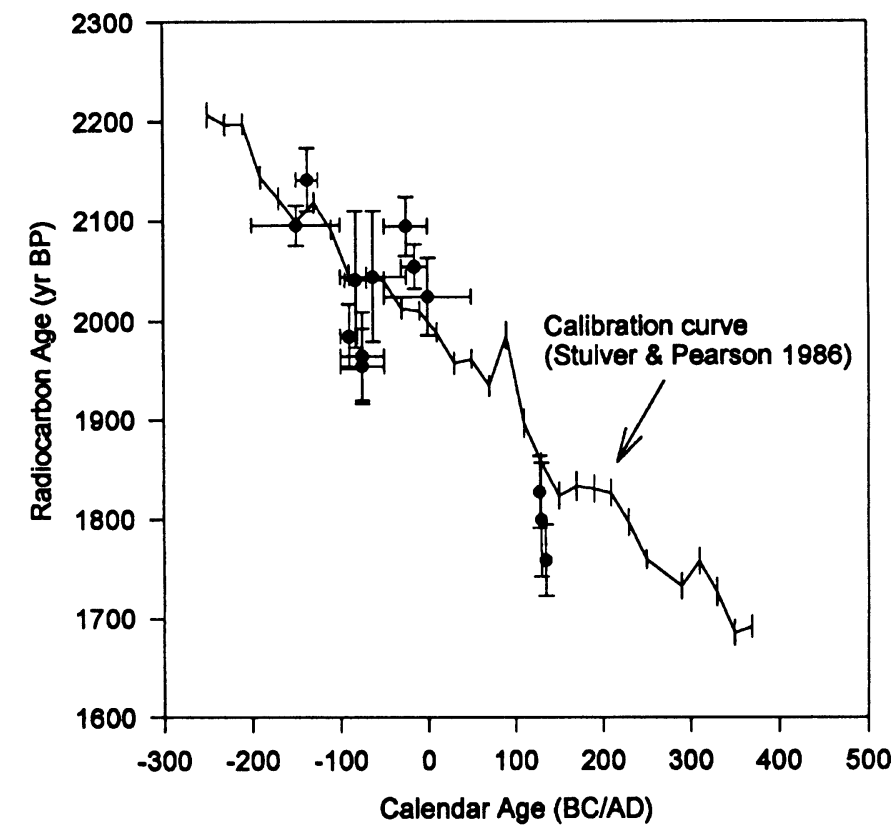

Fig. 2. Conventional ${ }^{14} \mathrm{C}$ age vs. calendar age. The solid curve shows the tree-ring calibration curve of Stuiver and Pearson (1986). The ordinate values for the data are conventional ${ }^{14} \mathrm{C}$ ages measured by AMS, as reported in Table 2 . The error bars on the ${ }^{14} \mathrm{C}$ ages are $1 \sigma$. The abscissa values for the data are estimates of paleographic age from Appendix 1.

is interesting that the three date-bearing papyri are all of approximately the same age, and there is a tendency for our measured age ranges to be on the younger side of these known ages. It is possible that the calibration curve for AD 135 should be slightly lowered, as its position appears to be determined by a single point in the 20 -yr calibration curve (Stuiver and Pearson 1986).

\section{Linen Fragments}

Two samples of linen, tested by AMS, yielded results in line with their anticipated dates based on context. These results are presented in Table 3. DSS-26 was a sample of cloth from Qumran Cave 4, to which a leather thong was attached, of the kind used to fasten the scrolls at Qumran (Carswell 1977). Significantly, the ${ }^{14} \mathrm{C}$ date for this sample fell solidly within the dating period established for the scrolls by both paleography and ${ }^{14} \mathrm{C}$ dating. DSS-27, a linen fragment with silk embroidery, was dated to the 12 th-13th centuries $A D$. This sample was bought from antiquity dealers who represented it as material "from Qumran cave 2"; it most probably originated from Wadi Murabba'at,

TABLE 3: Radiocarbon Dates on Linen Fragments from the Judean Desert

\begin{tabular}{|c|c|c|c|c|c|}
\hline Sample no. & Sample identification & $\begin{array}{l}\text { No. of } \\
\text { runs }\end{array}$ & $\begin{array}{l}\delta^{13} \mathrm{C} \\
(\% 0)\end{array}$ & $\begin{array}{l}{ }^{14} \mathrm{C} \text { age } \\
\text { (yr BP) }\end{array}$ & Calibrated age \\
\hline AA-13434 & $\begin{array}{l}\text { DSS-26, linen with leather thong } \\
\text { Cave } 4 \text {, inventory no. } 1041\end{array}$ & 2 & -26.5 & $2069 \pm 40$ & $\begin{array}{l}160-41 \text { BC }(1 \sigma) \\
193 \text { BC-AD } 11(2 \sigma)\end{array}$ \\
\hline AA-13435 & $\begin{array}{l}\text { DSS-27, linen, Cave } 2 \\
\text { inventory no. } 749\end{array}$ & 2 & -26.3 & $664 \pm 36$ & $\begin{array}{l}\text { AD } 1279-1376(1 \sigma) \\
\text { AD } 1270-1392(2 \sigma)\end{array}$ \\
\hline
\end{tabular}


where similar textiles were found (Crowfoot and Crowfoot 1961). Descriptions of these fragments are given in Appendix 2.

\section{CONCLUSION}

${ }^{14} \mathrm{C}$ ages of 14 parchment and 4 papyrus samples found in caves in the Judean Desert have been measured by AMS. Measurements on samples of known ages are in good agreement with those known ages. Ages determined from ${ }^{14} \mathrm{C}$ measurements on the remainder of the Dead Sea Scroll samples are in reasonable agreement with paleographic estimates of such ages, in the cases where those estimates are available.

\section{ACKNOWLEDGMENTS}

We are grateful to the Israel Antiquities Authority for permission to sample the Dead Sea Scrolls, and to the staff of the Rockefeller Museum and Israel Museum for assistance in sampling. We are grateful to those colleagues who suggested suitable texts for dating (G. Doudna, J. Greenfield, E. Larson, S. Pfann, E. Ulrich and G. Vermes). We also would like to thank L. J. Toolin, A. L. Hatheway and D. Biddulph for technical assistance in Arizona and Mrs. Claire Pfann for assistance in Jerusalem. The Arizona AMS Facility is supported in part by U.S. National Science Foundation grants EAR 92-03883 and 92-13638.

\section{REFERENCES}

Avigad, N. 1965. The palaeography of the Dead Sea Scrolls and related documents. In Rabin, C. and Yadin, Y., eds., Aspects of the Dead Sea Scrolls. Scripta Hierosolymitana 4, 2nd ed. Jerusalem, Magnes Press: 6574.

Baginski, A., and Shamir, O. 1995 Textiles from Jesiret Fara' un (Coral Island) No. 403/5, 403/6 and 403/7. In press.

Baumgarten, J. 1990 The 4 Q Zadokite fragments on skin disease. Journal of Jewish Studies 41: 153.

Baumgarten, J. 1992 The laws of the Damascus Document in current research. In Broshi, M., ed., The Damascus Document Reconsidered. Jerusalem, Israel Museum, Shrine of the Book: 51-62.

Bonani, G., Broshi, M., Carmi, I., Ivy, S., Strugnell, J. and Wölfli, W. 1991 Radiocarbon dating of the Dead Sea Scrolls. Atiqot 20: 27-32.

Bonani, G., Ivy, S., Wölfli, W., Broshi, M., Carmi, I. and Strugnell, J. 1992 Radiocarbon dating of fourteen Dead Sea Scrolls. Radiocarbon 34(3): 843-849.

Carswell, J., 1977 Fastening on the Qumran manuscripts. In de Vaux, R., ed., Qumran Grotte 4. Discoveries in the Judean Desert 6. Oxford, Oxford University Press 2: 23-28.

Cross, F. M., Jr. 1956 Le travail d'édition des manuscrits de Qumrân. Revue Biblique 75: 61. 1972 Introduction. In Trever, J. C., ed., Scrolls from Qumran Cave 1. Jerusalem, Albright Institute of Archaeology: 4.

1992 Some notes on a generation of Qumran studies. In Trebolle Barrera, L. and Vegas Montaner, L., eds., The Madrid Qumran Congress. Proceedings of the International Congress on the Dead Sea Scrolls, Madrid 18-21 March, 1991. Studies on the Texts of the Desert of Judah 11. Madrid and Leiden, Editorial Computense: 5 .

Crowfoot, G. M. 1955 The linen textiles. In Barthélemy, D. and Milik, J. T., eds., Qumran Cave I. Discoveries in the Judaean Desert 1. Oxford, Oxford University Press: $18-38$.

Crowfoot, G. M. and Crowfoot, E. 1961 The textiles and basketry. In Benoit, P., Milik, J. T. and de Vaux, R., eds., Les Grottes de Murabba'at. Discoveries in the Judean Desert 2. Oxford, Oxford University Press: 51-63.

Donahue, D. J., Jull, A. J. T. and Toolin, L. J. 1990 Some archaeological applications of accelerator radiocarbon analysis. Nuclear Instruments and Methods in Physics Research B45: 561-564.

Donahue, D. J., Linick, T. W. and Jull, A. J. T. 1990 Isotope-ratio and background corrections for accelerator mass spectrometry radiocarbon measurements. $R a$ diocarbon 32(2): 135-142.

Lamm, C. J. 1937 Some Mamluk embroideries. Ars Islamica 4: 65-76.

Lewis, N. 1989 The Documents from the Bar Kokhba Period in the Cave of Letters: The Greek Papyrii. Judean Desert Series 2. Jerusalem, Israel Exploration Society: $164 \mathrm{p}$.

Makie, L. 1989 Textiles. In Kubiak, W. and Scanlon, G. T., eds., Fustat Expedition Final Report. Vol. 2. Winona Lake, Indiana, American Research Center in 
Egypt: 81-101.

Milik, J. T. 1957 Deux documents inédits de Désert de Juda. Biblica 38: 264-268.

1959 Ten Years of Discovery in the Wilderness of Judaea. Studies in Biblical Theology 26. London, SCM Press: $160 \mathrm{p}$.

,ed. 1976 The Books of Enoch: Aramaic Fragments of Qumran Cave 4. Oxford, Clarendon: 439 p.

Puech, E. 1992 Une apocalypse messianique (4Q521). Revue Qumran 15: 480.

Sheffer, A. and Granger-Taylor, H. 1994. Textiles from Masada - a preliminary selection. In Masada: The Yigael Yadin Excavations 1963-1965: Final Reports. Jerusalem, Israel Exploration Society/Hebrew University of Jerusalem 4: 153-251.

Skehan, P. W., Ulrich, E. and Sanderson, J. 1992 Qumran Cave 4. Vol. 4. Palaeo-Hebrew and Greek Biblical Manuscripts. Discoveries in the Judaean Desert 9. Oxford: Clarendon: $258 \mathrm{p}$.

Stegemann, H. 1994 Die Essener, Qumran, Johannes der Täufer und Jesus: Ein Sachbuch. 4th ed. Freiburg im Breisgau, Pharos Publishing: 381 p.

Stuiver, M. and Becker, B. 1986 High-precision decadal calibration of the radiocarbon time scale, AD 19502500 BC. In Stuiver, M. and Kra, R. S., eds., Calibration Issue. Radiocarbon 28(2B): 863-910.
Stuiver, M. and Pearson, G. W. 1986 High-precision calibration of the radiocarbon time scale, AD 1950-500 BC. In Stuiver, M. and Kra, R. S., eds., Calibration Issue. Radiocarbon 28(2B): 805-838.

Stuiver, M. and Polach, H. A. 1977 Discussion: Reporting of ${ }^{14} \mathrm{C}$ Data. Radiocarbon 19(3): 355-363.

Stuiver, M. and Reimer, P. 1986 A computer program for radiocarbon age calibration. In Stuiver, M. and $\mathrm{Kra}$, R. S., eds., Calibration Issue. Radiocarbon 28(2B): 1022-1030.

Sussman, A. and Peled, R. 1993 Scrolls from the Dead Sea: An Exhibition of Scrolls and Archeological Artifacts from the Collections of the Israel Antiquities Authority. Washington, D.C., Library of Congress: 143 p.

Thompson, D. 1985 Cotton double cloths and embroidered and brocaded linen fabrics from tenth to fourteenth century Egypt. Bulletin de liaison du Centre International d'Etude des Textiles Anciens 61-62: 35-49.

Tov, E. and Pfann, S. J. 1995 Companion Volume to the Dead Sea Scrolls Microfiche Edition. 2nd rev. ed. Leiden, Brill/IDC.

Vermes, G. 1991 Qumran Corner. Journal of Jewish Studies 42: 250.

Vogelsang-Eastwood, G. 1993 Unearthing history: Archaeological textiles in Egypt. The International Mag. azine of Antique Carpet and Textile Art 67: 89.

\section{APPENDIX 1. DATES SUGGESTED FOR THE TEXTS ON THE BASIS OF PALEOGRAPHICAL ANALYSIS}

The information given below for scroll samples includes the $Q$ number, an abbreviated siglum following the name of the scroll, the PAM/Shrine photo number and the assigned paleographical date. The abbreviated sigla referring to the texts from the Judean Desert follow their conventional names. (For the most recent list, see Tov and Pfann (1995).) All photograph numbers are PAM (Palestine Archaeological Museum) numbers unless otherwise indicated.

DSS-1. 40266 Damascus document, $D^{*} \quad 43.277 \quad 100-50$ BC Comments: "The writing is in a semi-cursive Hasmonean hand which in Cross' paleographic sequence may be dated to the first half of the first century B.C.E." (Baumgarten 1992: 57). "The text is written in a semi-cursive Hasmonean hand which, in Cross's paleographic typology, may be assigned to the beginning of the first century B.C.E." (Baumgarten 1990: 153-165). 75-50 BC (Stegemann 1994: 166).

DSS-3. Commentary on Habakkuk, 1QpHab col. XIII Shrine 7203-4

30-1 BC

Comment: "The manuscript is written in an Early Herodian hand (ca. 30-1 B.C.), affecting the Palaeo-Hebrew script in a degenerate form when writing the Tetragrammaton" (Cross 1972: 4; Avigad 1965: 74).

DSS-4. Community Rule, $1 \mathrm{QS}$ col. XI

Shrine 7111

100-75 BC

Comments: "As we have seen, it belongs to a special semi-formal tradition of the Jewish script, a Hasmonean exemplar of this style from about 100-75 B.C." (Cross 1972: 4). "[A] date somewhat later than 1QIsaa is to be preferred" (Avigad 1965: 71).

DSS-5. $4 Q 258$ Community Rule, $S^{d}$

43.244

Beginning of 1st century BC

Comment: "The script of the oldest copy is dated by F. M. Cross to the beginning of the first Century B.C." (Vermes 1991: 250; Cross 1956: 61).

\section{DSS-7. $4 Q 171$ pPsa 41.303}

DSS-8. 4Q521 Mess. Apoc. $\quad 43.604 \quad 100-80$ BC Comment: "Cette écriture se placerait assez bien après celle de $1 \mathrm{QIsa}$ et $1 \mathrm{QS}$, dans le premier quart de $1^{\text {er }} \mathrm{s}$., entre 100 et 80 ,

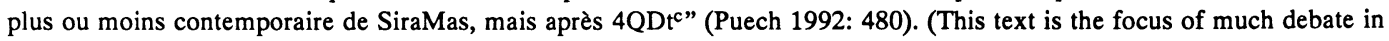
research, in particular with regard to its possible connection with early Christianity.) 
DSS-9. 4 Q267 Damascus Document, $D^{b}$

43.294

Comment: "[A] formal hand of the latter part of the first Century B.C.E." (Baumgarten 1992: 60).

$\begin{array}{llll}\text { DSS-10. } & 4 Q 249 & \text { pap Midrash Sefer Moshe } & 43.409 \\ \text { DSS-11. } & 4 Q 317 & \text { Phases of the Moon } & 42.424\end{array}$

DSS-13. 4Q208 Astronomical Enoch, Enastr" ar $43.210 \quad$ End 3rd/beginning 2nd century BC Comment: "The handwriting of Enastra is rather unusual, but fairly archaic; it resembles 'an archaic or early Hasmonaean semi-formal script of ca. 175-125 B.C.' (Cross [1961], p. 137, fig. I, line 6; cf. ibid., line 7 and p. 138, fig. 2, line I). It seems to me, however, to be older than the alphabets discussed by Cross, and to be related, by many a detail, to the writings of fig. I, lines 2-5. As a result I would date 4 QEnastra to the end of the third century or else the beginning of the second Century B.C." (Milik 1976: 273)

DSS-19. 4 Q22 paleoExodus, paleoExod ${ }^{m}$

42.582

$100-25$ BC

Comment: "[MacLean] has dated this scroll along with 4 QpaleoGen-Exod" $\ldots$ and $4 Q 124 \ldots$ within the period $100-50$ or $100-25 \mathrm{BC}$, with this qualification: 'Of these three contemporary manuscripts, I believe 4QpaleoExod ${ }^{\mathrm{m}}$ to display the latest features and the greatest number of novel features which will see subsequent development' (MacLean [1982], 78). On the basis of the extensive nature of MacLean's study, as well as Cross's endorsement of his conclusions, we accept his dating" (Skehan, Ulrich and Sanderson 1992: 62).

DSS-19a. 4Q22 paleoExod ${ }^{m}$ col. VIII (patch)

42.648

50 BC-AD 50

Comment: Skehan, Ulrich and Sanderson (1992: 85) state that "a patch was sewn from behind the leather to repair damage suffered by the MS after it had been inscribed." The patch thus had to be later than the manuscript itself; E. Ulrich (personal communication, 1995) dates it to $50 \mathrm{BC}-\mathrm{AD} 50$.

DSS-25. 5/6Hev 21 (pap Yadin 21) purchase of crop in Greek Shrine 5195 (Lewis 1989: pl. 26)

DSS-50. Book of Isaiah, 1QIsaa col. XXXIX

Shrine 7039

11 September AD 130

150-125 BC Comments: "[T]he old Isaiah scroll ... dates to c. 150-125 B.C.E." (Cross 1992: 5). "A date somewhere in the second half of the second century B.C.E. for Isaa , somewhat later than Nash, seems to be most reasonable and in keeping with the opinion of most scholars" (Avigad 1965: 69).

DSS-52. XHev /Se 8a pap sale of a house, Kefar Bebayou $\quad 40.996$ AD 135 (Milik 1957; 1959: 138 and p. 25)

DSS-53. 5/6Hev 19 (pap Yadin 19) deed of gift

(Lewis 1989: 83-87 and pl. 20)

Shrine 5185

16 April AD 128

\section{APPENDIX 2. LINEN FRAGMENTS}

Description by A. Baginski, Israel Antiquities Authority, Jerusalem.

DSS-26. Linen fragment with leather thong attached from Qumran Cave 4

Size: $3.0 \times 2.5 \mathrm{~cm}$. Warp: linen, cream S M $12 / \mathrm{cm}$. Weft: linen, cream S M 12/cm. Technique: balanced tabby sewing threads: linen $Z_{2} S$. Description: small triangular linen fragment, on one side remains of a rolled hem. A leather strip is sewn to one corner $(0.7 \times 4.0 \mathrm{~cm})$. The same box contains another small fragment of the leather thong $(0.6 \times 2.7 \mathrm{~cm})$ and a larger square piece of leather which is folded and has two slits $(2.7 \times 3.0 \mathrm{~cm})$, through which the thong was probably inserted. The linen fragment is very similar to some textiles from Qumran Cave 1; the leather thong and pieces are similar to those exhibited currently in the Israel Museum (Carswell 1977: 23-28; Crowfoot 1955: 37 no. 56, 38 no. 77, pl VII no. 26; Sussmann and Peled 1993: 114-115; Sheffer and Granger-Taylor 1994: 176 no. 102[A]).

DSS-27. Linen fragment with remains of silk embroidery from Qumran Cave 2

Size: $6.0 \times 4.5 \mathrm{~cm}$. Warp: linen, cream Z M 18/cm. Weft: linen, cream Z M 18/cm. Technique: balanced tabby weave. Decoration: embroidered, silk I, buff, darning stitches. Description: worn linen fragment with weaving faults; remains of silk embroidery, possibly of geometric pattern, but unrecognizable due to poor preservation. Fragment is most likely medieval or originating from Wadi Muraba'at, where similar textiles were found (Crowfoot and Crowfoot 1961: 51-63, pl. XVII no. 2; Lamm 1937: 65-76; Makie 1989: 81-101). 